\title{
New documents on Samuel Usque, the author of the Consolaçam as tribulaçoens de Israel
}

\author{
Maria Teresa GUERRINI
}

Scholars were so impressed by the wide knowledge of Jewish sacred books displayed by Samuel Usque in his Consolaçam as tribulaçoens de Israel that they wondered how and where he could have acquired it, and supposed that he must have studied in some oriental Yeshivah ${ }^{1}$.

Cecil Roth went further and imagined that Samuel had «emigrated to the Levant and settled in a congenial Cabbalist environment in Safed» ${ }^{2}$. However, he did not dispose of any documentary evidence and came to this conclusion only on the basis of Samuel's description of events which took place in Turkey ${ }^{3}$.

It was only at the end of the eighties that historians carried out archival researchs on the Portuguese Nation of Ferrara ${ }^{4}$ and provided some biographical information on Samuel Usque.

${ }^{1}$ H. Graetz, Geschichte der Juden, Band VIII (Leipzig 1907) Appendix IX: Die drei Usque; S. DuBNOw, Weltgeschichte der judischen Volkes, Band VI (Berlin 1927) pp. 20, 152-154.

2 C. Roth, «The Marrano Press at Ferrara, 1552-1555», Modern Language Review 38 (1943) pp. 307-317.

3 S. USQUE, Consolaçam às Tribulaçoens de Israel. Composto por Samuel Usque, Empresso en Ferrara en casa de Abraham aben Usque 5313 da criaçam, am d. 7 de setembro (available in the edição facsimilada published by the Fundacão Calouste Gulbenkian, Lisboa 1989) pp. 212v-214v, Third Dialogue: «33. Costantinopla, Año. 5302».

4 A. di Leone LEONI, «Gli ebrei sefarditi a Ferrara da Ercole I a Ercole II. Nuove ricerche e interpretazioni», Rassegna Mensile di Israel 52 (1987) pp. 407448; R. SEGRE, «La tipografia ebraica a Ferrara e la stampa della Biblia (155159)», Italia Medievale ed Umanistica 35 (1992) pp. 305-332. 
During the last three years, I have been carrying out some research in the State Archives of Ferrara (= ASFe), Venice (= ASVe) and Ancona (= ASAn), in order to find new information on the life of the poet and on his extra-literary activities.

In 1543, Usque lived in Antwerp and had been at the service of Diogo Mendes' house 5 . In the same period, Duarte Pinel (alias Abraham Usque) and Lionel Pardo were also in Flanders. Their names were included in a list of Portuguese people drawn up by the Imperial Police ${ }^{6}$. We cannot state if Samuel appeared in the same or in a similar list, as we do not know, so far, his baptismal name.

So, from the 1549 notary deed we learn that after Diogo Mendes' death, Samuel worked for Brianda Mendes de Luna (Diogo's widow) for an undetermined period; then Samuel left Antwerp and undertook the difficil caminho through the Alps, towards Italy ${ }^{7}$, at least one year before Beatriz and Brianda de Luna made their famous escape to Venice ${ }^{8}$.

In 1545 Samuel was in Ancona and described himself as a Portuguese merchant. On august 6th $1545{ }^{9}$ two Christians swordsmiths from Brescia, Bettino and Tommaso Lantani, who at the time lived in Ancona, acknowledged to owe Samuel the amount of 657 golden ducats corresponding to the value of 13.500 pounds of raw wool, which they agreed to pay within four months.

On December 24th 1545, the two Lantani still had not settled their debt. As Samuel happened to owe Salomon Calvo, another Portuguese merchant of Ancona, the amount of 518 ducats, he

5 This may be inferred from a 1549 notary deed. See ASFe, notary Pietro Antonio Franchi, matr. 495, p. 3, 24 September 1549, Compromissum inter Samuelem Usque et dominam Briandam de Luna: «Samuel ... habere debito pretendit a dicta domina Brianda pro eius Samuelis mercede inserviendi sibi domine Briande in Anversa post mortem domini Dieghi Mendes».

${ }^{6} \mathrm{I}$ am indebted for this information to Dr. Aron Leoni. The document is conserved at the Archives Générales du Royame en Belgique and will be published by this author in his History of the Portuguese Nation.

7 UsQue Consolaçam pp. 216r-217v, Third Dialogue: «36. Ytalia, Año. 5311».

8 P. Grunebaum-Ballin, Joseph Naci, Duc de Naxos (Paris - La Haye 1968) p. 45 .

${ }^{9}$ See A. LEONI, «La Nation Portughesa corteggiata, privilegiata, espulsa e riammessa a Ferrara (1538-1550)», in the press of a special number of Rivista Italia: ASAn, notary Bernardino Pavesi, matr. 244, b. 967, 6 August 1545, Samuel Usque de Portugalia cum Bettino de Dominico Lantani et socio de Brisia, armaroli [...?] promissio. 
settled his debt by means of a Cessio Iurium and transferred to Salomon part of his credit with the Lantani ${ }^{10}$.

On July 5th $1546{ }^{11}$, in Ferrara, the Lantani delivered to Samuel Usque 1.000 sword-blades for a total value of 207 ducats, 50 ducats more than what was owed directly to Samuel who had to pay this difference in cash ${ }^{12}$.

In the second half of 1546, Salomon Calvo settled in Ferrara. $\mathrm{He}$ had not been able to cash his credit from the Lantani and complained to Samuel who, in his opinion, had to pass the 50 ducats over to him. A quarrel broke out and was resolved up by means of a compromise registered by the notary Giacomo Conti ${ }^{13}$ : Samuel took upon himself the responsability of recovering also Salomon's credit from the Lantani and for this purpose enstrusted Alvaro Dies, a Portuguese merchant of Ferrara, with this task ${ }^{14}$. Apparently Alvaro's mission was not successful.

In the meantime the 1.000 blades sold to Samuel turned out to be of poor quality. A new quarrel broke out between the two Portuguese merchants. The case was brought to the court: Salomon was put in jail even before a sentence was pronounced and, at the request of Samuel ${ }^{15}$, the representatives of the Portuguese Nation came to the aid of Salomon. Yoseph Navarro (alias Petro Pignero) ${ }^{16}$, Hezra Vezinho (alias Francisco Mendes), Sebastian Pinto and David Francho engaged themselves to pay

10 LEONI «La Nation Portughesa»: ASAn, notary Bernardino Pavesi, matr. 244, b. 967, 24 December 1545, Salomonis Calvo de Portugalia. Cessio iurium.

11 See A. LEONI, «La diplomazia estense e l'immigrazione dei cristiani nuovi a Ferrara al tempo di Ercole II», Nuova Rivista Storica 2 (maggio-agosto 1994) p. 321: ASFe, notary Giacomo Conti, matr. 584, pp. 2 and 4, 5 July 1546, Consignatio et solutio pro Samuele Usque lusitano.

12 The value for the blades made up for the difference between the 675 ducats originally due to Samuel and the 518 he received from Salomon Calvo plus the 50 ducats added by Samuel.

13 ASFe, notary Giacomo Conti, matr. 584, pp. 3 and 4, 14 October 1546, Transactio inter Samuelem Usque et Salomonem Calvo.

14 See LEONI «La Nation Portughesa»: ASFe, notary Giacomo Conti, matr. 584, pp. 3 and 4, 14 October 1546, Mandatum Samuelis Usque in dominum Alverum Dies.

15 ASFe, notary Giovanni Maria Agolanti, matr. 464, p. 9, 12 March 1547, Promissio ad favorem Samuel Usque lusitanus; Ibid., Conservatio indemnitatis predicti David, Joseph et Hezra; Ibid., Conservatio indemnitatis Sebastiani Pinti a Odoardo Sola.

16 Both the Jewish and the Christian names are mentioned in the deed. 
whatever amount of money Calvo might be ordered to pay by the Tribunal, also on account of «expenses». Thanks to their guarantee, Salomon was freed from prison ${ }^{17}$.

The litigation was settled three years later on July 13th $1550{ }^{18}$ by means of another arbitration. The judgement, drawn up by Gulielmo Fernandes in the house of Beatriz de Luna (Gracia Naci), stated that Usque (represented by Fernando Mendes) had to give Salomon Calvo 100 golden ducats and 300 sword blades which Samuel evidently had been unable to sell.

The whole history, perhaps a little bit boring, is very important and provides new information on Samuel's activities: in 1545 he was a mercator in Ancona, he later moved to Ferrara where he led an unpretentious way of life. The sums of money available to him were rather modest and he did not display particular skill in his business affairs. These were the reasons why Samuel started to work for Brianda Mendes again.

In 1548 Samuel was in Venice, apparently in the service of Brianda de Luna but we do not know if he lived in her mansion, in the Ghetto or somewhere else. On June 20th $1548{ }^{19}$ he was found guilty of wearing a black hat instead of the yellow one imposed on the Jews ${ }^{20}$ and was sentenced by the Avogadori ('judges') de Comun to a 30-day term and to a fine of 50 golden ducats. The punishment was mitigated and reduced to half. It may hence be inferred that Samuel declared himself to be Jewish and that this was the first time that he was caught with a black hat, otherwise, the punishment would not have been reduced. Luckily enough, the Venetian judges did not question the origins of

\footnotetext{
17 Two years before, the same Yoseph Navarro, Ezra Vezinho and Sebastian Pinto, together with other Portuguese merchants, both in their own name and in their capacity as representatives of the Portuguese Nation of Ferrara, had provided a similar guarantee in favour of Enrico and Stefano de Pirris who were debtors to the Ducal Chamber for the huge amount of 23.500 golden ducats, owing to their unsuccessful management of a commercial company the main investor of which was the Duke. See LEONI «La Nation Portughesa».

18 ASFe, notary Giacomo Conti, matr. 584, p. 4, 13 July 1550, Absolutio Samuelis Usque lusitani a Salomone Calvo.

19 ASVe, Avogaria de Comun, Raspe, reg. 3675/35, 20 june 1548.

20 See the decree by the Senate (ASVe, Senato-Terra, Decreti, reg. 12, 26 March 1496) which draw inspiration from a law by the Maggior Consiglio (ASVe, Maggior Consiglio, Deliberazioni, Leona 21, 5 may 1409).
} 
Samuel's Jewishness and he was not dealt with as a Marrano. The 25 ducats fine was paid by Brianda Mendes ${ }^{21}$.

Their relationship was severed in September 1549 when Brianda brought unspecified accusations against Samuel who was in Ferrara's jail 22 . He was set free when he complied with her request to undersign a certain document ${ }^{23}$. In the same deed Samuel expressed his bitterness and maintained that he had signed under constriction only for the purpose of obtaining his release from prison.

Two days later, with separated deeds ${ }^{24}$, Samuel (out of the prison) and Brianda appointed three arbitrators (Lupo Pignero, Pietro Fernandes and Francesco Nunes) to establish the amount of money Brianda owed Samuel in settlement of his wages for the periods he had been in her service in Antwerp (after Diogo Mendes' death), in Venice and in Ferrara ${ }^{25}$.

The arbiters stated that Brianda owed Samuel 200 scudi to be paid in two instalments: 100 scudi immediately, before Usque should leave her home, and the rest one year later. Furthemore, Brianda had to draw up a declaration stating that Samuel was in good health and was leaving Ferrara for reasons other than the

21 ASFe, notary Pietro Antonio Franchi, matr. 495, p. 3, 11 October 1549, Laudum inter nobilem dominam Briandam de Luna et Samuelem Usque with the arbitration.

22 See R. SEgRE, «La formazione di una comunità marrana: i portoghesi a Ferrara», in Storia d 'Italia, Annali 11: Gli ebrei in Italia, ed. C. VIVANTI, vol. I, Dall 'alto Medioevo all 'età dei ghetti (Torino 1996) pp. 779-841: p. 798: ASFe, notary Giacomo Conti, matr. 584, p. 4, 22 September 1549, Protestatio et declaratio pro Samuele Usque hebreo lusitano: «... Samuel Usque lusitanus de presenti incarceratus in dicto carcere Communis Ferrarie noncupato la Salla constitutus ibidem ad fenestrellam dicti carceris ...».

${ }^{23}$ The document mentioned in the notary deed of 22 September 1549 is unknown to us.

${ }^{24}$ ASFe, notary Pietro Antonio Franchi, matr. 495, p. 3, 24 September 1549, Compromissum inter Samuelem Usque et dominam Briandam de Luna; Ibid., Absolutio domine Briande de Luna a Samuele Usque cum credito dicti Samuelis; Ibid., 25 september 1549, Compromissum domine Briande de Luna in Samuelem Usque; Ibid., Compromissum Samuelis Usque in dominam Briandam de Luna.

${ }^{25}$ See note 21 . It is in fact from this arbitrary sentence that we learnt that Samuel was arrested in Venice in 1548 and sentenced to 15 days jail and to a 25 ducats fine which was paid on his behalf by Brianda together with all the judicial expenses. 
plague which had hit the town ${ }^{26}$. Samuel was sentenced «to keep perpetually silent» and never to talk about it nor to advance further claims.

Samuel went to Pesaro ${ }^{27}$ where he apparently remained at least for one year. In a deed drawn on November 19th $1550{ }^{28}$ Samuel stated to be «habitator Pensauri et Ferrarie nunc degens» ('living in Pesaro and provisonally stying in Ferrara'). He entrusted Fernando Mendes ${ }^{29}$ with the charge of collecting from Pinhero the second and last instalment of 100 scudi which Brianda owed him. Apparently Samuel used this money to settle his quarrel with Salomon Calvo, as we have already seen.

The last deed concerning Samuel Usque in Ferrara was written on February 17th $1553{ }^{30}$ when he sold a certain Hieronymo Brachi silk clothes to value of 155 lire.

Thus, we have been able to follow the tracks of the writer and the sequence of his movements from Antwerp to Ancona then to Ferrara, to Venice and back again to Ferrara and Pesaro. We do not know his exact movements between 1551 and 1553 and we cannot exclude the idea that Usque spent a short time in the Near East though not long enough to acquire his wide culture: eventually, he merely improved what he had already learnt before. In any case this could also be done in Ferrara which, at the time, was a famous center of Jewish learning.

In 1553 Usque's masterpiece and sole work, the Consolaçam as tribulaçoens de Israel, came to light in Ferrara. Since this book is dedicated to Doña Gracia Naci, it is generally believed that the Great Lady supported economically Usque's litterary efforts.

${ }^{26}$ On the subject of the plague in Ferrara and the subsequent expulsion of Portuguese people from this town see the discussion in A. di Leone LEONI, «Manoel Lopez Bichacho a XVIth Century Leader of the Portuguese Nation in Antwerp and in Pesaro», Sefarad 59 (1999) pp. 77-100.

27 See Usque Consolaçam pp. 217v-218v, Third Dialogue: «37. Pesaro, Año. 5313».

28 ASFe, notary Giacomo Conti, matr. 584, p. 4, 19 november 1550, Mandatum Samuelis Usque in dominum Fernandum Mendes.

${ }^{29}$ The famous lawyer and member, together with Gulielmo Fernandes, of Beatriz' circle.

30 ASFe, notary Giacomo Conti, matr. 584, p. 5, 17 february 1553, Creditum Samuelis Usque in ser Hieronimum de Brachis. 
We have found wide evidence of the fact that Doña Gracia extended her protection to Samuel: the top managers of her commercial house and other members of her circle took care of Samuel when he was arrested in Ferrara, they succeded in getting him free and in securing from Brianda the payment of his wages.

The relationschip between the poet and Doña Gracia Naci was not prolonged: in the spring of 1551 Beatriz left Ferrara for Venice whence she moved to Istambul in $1552^{31}$. When the Consolaçam came to light Gracia was no longer in Italy.

Nothing however allows us to disprove the general belief that Samuel Usque and Doña Gracia acted together in order to convince the Marranos to return ostensibly to Judaism and to the practice of the «verdadeira ley de seus padres, que por tantos annos a tras aviam jaa deixado e esquecido» ${ }^{32}$.

\section{RESUMEN}

Samuel Usque, literato y mercader en Ferrara en el siglo XVI, compartió con Beatriz de Luna [Gracia Nasí] el ya bien conocido proyecto cultural de la reeducación de los marranos en el judaísmo. Además, Samuel Usque estuvo también al servicio de Brianda Mendez como mercader en Amberes, Ferrara, Venezia y Ancona.

\section{SUMMARY}

Samuel Usque was a sixteenth-century Ferrara merchant and man of letters. Usque and Beatriz de Luna [Gracia Nasi] collaborated in the well-known task of reeducating Marranos in the precepts of normative Judaism. In addition, he represented Brianda Mendes in business trading in Antwerp, Ferrara, Venice and Ancona.

${ }^{31}$ In Istambul Beatriz assumed the Jewish name of Gracia, by which she is better known to scholars. See H. P. SALOMON and A. di Leone LEONI, «Mendes, Benveniste, de Luna, Micas, Nasci: the State of the Art (1532-1558)», Jewish Quarterly Review 88 (1998) pp. 135-211.

32 USQUE Consolaçam p. $210 \mathrm{r}$. 